\title{
Leadership in anaesthesia: A brief review
}

\section{Arpan Guha}

\section{INTRODUCTION}

Medical curricula and training syllabi are full of clinical knowledge and skills lists that must be acquired for advancing in the profession. At a practical level, every clinician has to take on a leadership responsibility on a daily basis. However, there seems to be a paucity of declared intent in training programmes regarding leadership. Even if there is a mention of 'leadership' as a desirable attribute, in curricula, there can be a lack of guidance on how this may be delivered, or indeed what a competency framework for leadership might look like.

For this discussion, leadership in health care may be artificially divided into two categories, although in reality this is a graded attribute. One is a form of leadership that is seen at the board level in most hospitals where leaders can be clearly identified by their designation, e.g. Medical Director. However, while only a few doctors may aspire for these kinds of organisational leadership roles, it is an inescapable fact that leadership demonstrated daily in the clinical workplace is also vitally important, especially when patient safety is paramount. The latter is the form of leadership skill that must be acquired by every clinician; however, many training schemes lack this focus. For example, the National Board of Examinations of India in its anaesthesiology syllabus mentions the word 'leadership' only once and in passing. ${ }^{[1]}$

This article aims to review briefly the framework that may support development attributes such as medical leadership, with a reference to anaesthesiology, where this non-technical skill assumes even greater importance.

Postgraduate School of Medicine, University of Liverpool, Liverpool, UK

\begin{tabular}{|l|l|}
\hline \multicolumn{2}{|c|}{ Access this article online } \\
\hline Quick Response Code: & Website: \\
\hline & www.jnaccjournal.org \\
\hline & \\
\hline
\end{tabular}

\section{LEADERSHIP IN MEDICINE: A VIEW FROM THE UK}

The undergraduate and postgraduate training of doctors in the UK is governed by guidance from the General Medical Council (GMC). GMC highlights that leadership is a part of a doctor's professional makeup. The GMC's document 'Tomorrow's Doctors' ${ }^{[2]}$ states: 'It is not enough for a clinician to act as a practitioner in their own discipline. They are expected to offer leadership and to work with others to change systems when it is necessary for the benefit of patients.'

The Academy of Medical Royal Colleges of the UK has also developed the Medical Leadership Competency Framework (MLCF) ${ }^{[3]}$

At the heart of MLCF lies the concept of 'shared leadership', meaning that this framework is not restricted to those in obvious leadership roles. Therefore, it is designed to facilitate multi-disciplinary team working and a facilitative leadership style. If one considers the practicalities of delivering clinical medicine to patients, it becomes obvious that this framework is aligned to the practice on the ground.

The domains described in the framework ${ }^{[3]}$ are as follows:

- Demonstrating personal qualities

- Working with others

- Managing services

- Improving services

- Setting direction.

The framework is therefore designed to start leadership understanding at an earlier stage of the profession by first understanding the 'self', and then supportively develop these concepts into higher leadership functions, such as 'setting direction'. This framework allows application

This is an open access article distributed under the terms of the Creative Commons Attribution-NonCommercial-ShareAlike 3.0 License, which allows others to remix, tweak, and build upon the work non-commercially, as long as the author is credited and the new creations are licensed under the identical terms.

For reprints contact: reprints@medknow.com

How to cite this article: Guha A. Leadership in anaesthesia: A brief review. J Neuroanaesthesiol Crit Care 2016;3:53-5. 
across both the domains of organisational leadership and also the day-to-day clinical practice described above, i.e., by demonstrating personal qualities, team working skills and local direction setting.

\section{LEADERSHIP IN MEDICINE: THE VIEW FROM INDIA}

Although previous guidance from the Medical Council of India did not have an 'in depth' view of leadership in medicine, the more recent document that articulates the vision of postgraduate and undergraduate medical education in India for the future is promising. ${ }^{[4]}$ There is now amore explicit reference to leadership and even lists of competencies which include working in teams, understanding team roles and higher skill of making an impact on public health and policy. Hence, there seems to be a move towards promoting internationally accepted non-technical skills in medicine in the Indian context.

\section{THE CONCEPT OF SHARED LEADERSHIP IN ANAESTHESIA}

There is also broader question of the socio-cultural environment in which leadership training is contextualised. There seems to be an acknowledgement that there is a paucity of medical leadership in India, in general ${ }^{[5]}$ and some authors even describing it as a 'leadership crisis. ${ }^{[6]}$

With the above background in mind, it is useful to consider what leadership in anaesthesia might mean and how anaesthesia teams may develop. This question is also intimately linked to the function of the anaesthesia team.

One of the models of leadership that have been shown to be effective in the speciality of anaesthesia is the concept of shared leadership. ${ }^{[7]}$ In this model, there is recognition that certain medical specialists, such as anaesthesiologists, work in complex and dynamic environments. The ever-changing nature of the work, therefore, demands a model of leadership that changes with need and is not fixed. It has been shown that when anaesthesiologists and nurses, for example, share leadership in an adaptive way, the performance of the team is significantly better than when leadership is delivered only by medical anaesthesiologists. ${ }^{[7]}$ This demonstrates clearly that the impact of non-technical skills can be paramount for a better patient experience, especially during situations of high stress and consequent work overload, which can be the hallmark of the speciality of anaesthesia.

\section{HOW MAY WE DELIVER LEADERSHIP THIS LEARNING?}

Once we accept that leadership knowledge, skills and behaviour are important for the anaesthetist and also acknowledge shared leadership of the anaesthesia team as being desirable, there are a number of options to create these learning opportunities. One method that can be used effectively is using simulation scenarios using responsive manikins.

As it is acknowledged that leadership in anaesthesia becomes important in times of clinical crisis, it is important to learn leadership skills in that context but in a safe environment. Our group has shown previously that high fidelity patient simulation suing immersive techniques and manikin technology allows this, and there is evidence that these skills can be practised and retained for a relatively longer term. ${ }^{[8]}$

It is also known that trainees in anaesthesia prefer to learn the behavioural elements of their clinical practice (i.e., non-technical skills) in a simulation environment, rather than traditional knowledge-based learning delivered via simulation. ${ }^{[9]}$ Clearly, this lends itself to delivering courses based on leadership ad team working using simulation.

In recent times, it has even become possible to use tools to assess the development of the leadership and team working skills over time. ${ }^{[10]}$ This can be valuable in providing continuous and graded feedback as skills develop.

The ultimate beneficiary of such training is for the patient. The consequence of good leadership and team training is that hierarchical decisions made erroneously can be challenged, with the consequence of enhanced patient safety. ${ }^{[11]}$

\section{CONCLUSION}

It is recognised that every health economy needs strong leadership as the complexity of healthcare needs of the population and costs to deliver it increase. In addition, patient safety is an integral part of healthcare function. Leadership and indeed other non-technical skills, such as communication, should be considered a core element of training and given equal importance to clinical subjects. We should all collectively aspire to achieve that goal. A number of different ways of delivering these goals are variable and should be fully considered and simulation facelifted learning has a large role to play in the learning of such non-technical skills in anaesthesia.

\section{Financial support and sponsorship} Nil.

\section{Conflicts of interest}

There are no conflicts of interest. 


\section{REFERENCES}

1. Available from: http://www.natboard.edu.in/notice_for_dnb candidates/anaesthesia.pdf. [Last accessed on 2015 Nov 06].

2. Tomorrow's Doctors Outcomes and Standards for Undergraduate Medical Education. General Medical Council, UK; 2009. Available from: http://www.gmc-uk. org/Tomorrow_s_Doctors_1214.pdf_48905759.pdf. [Last accessed on 2015 Nov 06].

3. NHS Institute for Innovation and Improvement and Academy of Medical Royal Colleges. Medical Leadership Competency Framework. $3^{\text {rd }}$ ed. Coventry: NHS Institute for Innovation and Improvement; 2010. Available from: http://www.aomrc.org. uk/doc_view/9539-nhs-leadership-framework. [Last accessed on 2015 Nov 06].

4. Vision 2015. Medical Council of India; 2011. Available from: http://www.mciindia.org/tools/announcement/MCI_booklet. pdf. [Last accessed on 2015 Nov 06].

5. Jindal SK. Leadership in medicine. Indian J Chest Dis Allied Sci 2014;56:69-70.

6. Kumar R. The leadership crisis of medical profession in India:
Ongoing impact on the health system. J Family Med Prim Care 2015;4:159-61.

7. Kuinzle B, Zala-Mezö E, Wacker J, Kolbe M, Spahn DR, Grote G. Leadership in anaesthesia teams: The most effective leadership is shared. Qual Saf Health Care 2010;19:e46.

8. Kuduvalli PM, Parker CJ, Leuwer M, Guha A. Retention and transferability of team resource management skills in anaesthetic emergencies: The long-term impact of a high-fidelity simulation-based course. Eur J Anaesthesiol 2009;26:17-22.

9. Mercer SJ, Moneypenny MJ, Fredy O, Guha A. What should be included in a simulation course for anaesthetists? The Merseyside trainee perspective. Eur J Anaesthesiol 2012;29:137-42.

10. O'Sullivan H, Guha A, Moneypenny M. Assessing leadership skills in medical undergraduates. In: $\mathrm{K} \mathrm{J} \mathrm{S}$, itors Essential Simulation in Clinical Education. Wiley-Blackwell: p. 238.

11. Moneypenny MJ, Guha A, Mercer SJ, O'Sullivan H, McKimm J. Don't follow your leader: Challenging erroneous decisions. Br J Hosp Med (Lond) 2013;74:687-90. 